\title{
Hormonal Regulation of Protein Synthesis in Rat Ventral Prostate
}

\author{
Shogo ICHII, Masao IZAWA AND Noriko MuraKami \\ Division of Physiology, Institute of Steroid \\ Research, Tottori University School of Medicine, Yonago 683
}

\begin{abstract}
Synopsis
To elucidate details of hormonal regulation mechanism in rat ventral prostate, synthesis of RNAs that contain polyadenylate sequences, polyribosomal sedimentation profile, ribosomal capacity of ${ }^{3} \mathrm{H}$-Met-tRNA binding, ribosomal initiation factor activity and the rate of polypeptide chain elongation were examined in the ventral prostate from control and castrated animals. The following results were obtained;1) The concentration of RNAs that contain polyadenylate sequences in cytoplasm of castrated rats was markedly decreased, while the content in nuclear fraction was not influenced significantly by castration. 2) Polyribosomes disappeared quite rapidly after castration and were completely restored $48 \mathrm{hr}$ after testosterone administration. 3) Ribosomal binding capacity with ${ }^{3} \mathrm{H}$-Met-tRNA and ribosomal initiation factor activity were also reduced significantly. Testosterone treatment of castrated animals completely abolished the effect of castration on ribosomal binding capacity with ${ }^{3} \mathrm{H}$-Met-tRNA and initiation factor activity. 4) A relatively small effect of castration on the relative rate of polypeptide chain elongation in rat ventral prostates was observed. These results may indicate that the regulation of protein synthesis exerted by testosterone in rat ventral prostates is not restricted at the step of the transcription of mRNA.
\end{abstract}

The effect of androgen on the protein synthesis in male accessary sex organs has mostly been attributed to the formation of new mRNAs and ribosomes (see a review by WilliamsAshman and Shimazaki, 1969). However, there has been considerable evidence to suggest that the protein synthesis is regulated at the posttranscriptional level (Thompson et al., 1970; Tomkins et al., 1972). It has also been claimed by several investigators that the rate determining step in the protein synthesis occurs

Received for publication March 11, 1974.

Abbreviations used; Met-tRNA; Methionine accepting transfer ribonucleic acid, ${ }^{3} \mathrm{H}-\mathrm{Met}-\mathrm{tRNA}$; tRNA which was charged with ${ }^{3} \mathrm{H}$-methionine, poly $\mathrm{A}$; polynucleotide of adenylate, poly $\mathrm{U}$; a synthetic polynucleotide of ulidylate, poly AUG; a synthetic polynucleotide of adenylate, uridylate and guanylate (1:1:1). during the initiation phase of the translation (Fleck et al., 1965; Stirewalt et al., 1967; Vaughan et al., 1971; Van Venrooji et al., 1972; Pain, 1973).

To elucidate details of hormonal regulation mechanisms of protein synthesis in one of the androgen target tissues, we compared the rate of synthesis of RNAs that contain polyadenylate sequences (poly A-RNA), polyribosomal sedimentation profile, ribosomal capacity of ${ }^{3} \mathrm{H}$-Met-tRNA binding, ribosomal initiation factor (IF) activity and the rate of polypeptide chain elongation in ventral prostates from castrated rats with the above rate in control rats. In some experiments, the effect of testosterone administration to castrated animals was also examined. The results obtained will be described as follows. 


\section{Materials and Methods}

\section{Animals}

Male Wistar rats weighing 300-350 g were used. They were fed ad libitum with balanced diet (Clea CA-1, Nippon Clea K.K. Tokyo) and kept in a room of constant temperature $\left(25^{\circ} \mathrm{C}\right)$ and humidity $(60 \%)$ with 7 a.m. -7 p.m. day-light cycle. Castration was performed via scrotal route under ether anesthesia. Sham-operations were performed in the same manner except that testes were not removed. For replacement therapy of castrated animals, $2 \mathrm{mg}$ of testosterone propionate dissolved in $0.1 \mathrm{ml}$ of cotton seed oil were injected subcutaneously to each animal once every $24 \mathrm{hrs}$ and in most cases they were sacrificed for experiments $12 \mathrm{hrs}$ after the last hormone administration.

\section{Determination of poly A-RNA in nuclear and cytoplasmic fractions}

The method used for the determination of poly A-RNA was essentially the same as described by Sheldon et al. (1972). $1.2 \mathrm{mCi}$ of ${ }^{32} \mathrm{P}$-orthophosphate were injected to each rat intraperitoneally and animals were sacrificed $40 \mathrm{~min}$ postinjection. Approximately $2 \mathrm{~g}$ of the tissue (from 6 control rats or from 8 castrated rats) were pooled and homogenized with 7 volumes of ice-cold medium containing $250 \mathrm{mM}$ sucrose, $25 \mathrm{mM} \mathrm{KCl}, 5 \mathrm{mM} \mathrm{MgCl}_{2}$ and $50 \mathrm{mM}$ Tris- $\mathrm{HCl}(\mathrm{pH}$ 7.6). The homogenate was centrifuged at $700 \times \mathrm{g}$ to separate the nuclear fraction from cytoplasmic one. RNA was extracted from these two fractions by the SDS-phenol method of Lee et al. (1971) with minor modifications. $200 \mu \mathrm{g}$ of poly $U$ (Boehringer, Mannheim, Germany) were dissolved in distilled water and applied onto fiberglass filter (Whatman GF/C, $2.4 \mathrm{~cm}$ ), dried and irradiated with UV-Lamp as described by Sheldon et al. (1972). Extracted RNA in which the relative concentration of poly A-RNA is to be determined was dissolved in a medium containing $10 \mathrm{mM}$ Tris- $\mathrm{HCj}(\mathrm{pH} 7.5)$ and $120 \mathrm{mM} \mathrm{NaCl}$ and applied onto a poly $\mathrm{U}$ filter. The filtration was performed by light suction at the rate of $1.0 \mathrm{ml} / \mathrm{min}$, followed by washing the filter with $30 \mathrm{ml}$ of the buffer and $10 \mathrm{ml}$ of $5 \%$ trichloroacetic acid. The radioactivity retained on the dried filter was counted in a liquid scintillation spectrometer. Almost linear relationship was observed between the amount of the radioactivity retained on the poly $U$ filter and the amount of imput RNA within a limited range of imput RNA. Three different amounts of RNA was applied to the filter for each assay and an average was taken as the rate of poly A-RNA concentration.

\section{Ribosomal sedimentation profiles}

The homogenate of the ventral prostate prepared as described above was fractionated by the method of Wettstein et al. (1963) and polysomal pellets were precipitated from the postmitochondrial fraction through a discontinuous sucrose gradient of 0.5 and $2.0 \mathrm{M}$ after addition of sodium deoxycholate at the final concentration of $0.5 \%$. The pellets were resuspended in the medium used for the homogenization and layered on a continuous sucrose gradient $(0.3 \mathrm{M}$ to $1.0 \mathrm{M}$ ). After centrifugation in a Hitachi RPS $25 \mathrm{~A}$ rotor at $25,000 \mathrm{rpm}$ for $2 \mathrm{hr}$, each $1 \mathrm{ml}$ fraction was taken from the top of the gradient and UV-absorption at $260 \mathrm{~nm}$ was determined.

\section{Preparation of ribosomes, initiation factor (IF)} fraction and ${ }^{3} \mathrm{H}$-Met-tRNA

Ventral prostates obtained from 15 intact control, 12 hormone-treated and 20 castrated rats were pooled by each group and homogenized in 2 volumes of the homogenizing medium. Ribosomes were separated according to the method described by Schreier and Staehelin (1973a) through a cushion of $2 \mathrm{M}$ sucrose. Ribosomal pellets were suspended in $1.2 \mathrm{ml}$ of a medium containing $50 \mathrm{mM}$ Tris- $\mathrm{HCl}$ (pH 7.6), $10 \mathrm{mM}$ $\mathrm{MgCl}_{2}, 100 \mathrm{mM} \mathrm{NH}_{4} \mathrm{Cl}$ and $4 \mathrm{mM}$ mercaptoethanol. An aliquot of this suspension was used for the determination of ${ }^{3} \mathrm{H}$-Met-tRNA binding capacity and another aliquot was used for the preparation of IF fraction.

The IF fraction was prepared essentially according to the method described by Schreier and Staehelin (1973a). To the suspension of ribosomes, $4 \mathrm{M} \mathrm{KCl}$ solution was slowly added to make the final concentration of $0.5 \mathrm{M}$ with respect to the total salt concentration and stirred for $60 \mathrm{~min}$ at $0^{\circ} \mathrm{C}$. Ribosomes were removed from this suspension by centrifugation at $250,000 \times \mathrm{g}$ for $100 \mathrm{~min}$ and the supernatant was dialysed overnight against a large volume of medium which consisted of $10 \%$ glycerol, $20 \mathrm{mM}$ Tris- $\mathrm{HCl}$ (pH 7.6), 0.5 mM EDTA and $4 \mathrm{mM}$ mercaptoethanol. An aliquot of this dialysate was used for the determination of IF activity. Rat liver IF was prepared by almost the same method but the ribosomal salt-wash fraction was further fractionated by $\left(\mathrm{NH}_{4}\right)_{2} \mathrm{SO}_{4}$, the precipitate obtained between $35 \%$ and $80 \%$ saturation was dialyzed and used for the experiment.

tRNA was prepared from rat livers by the method of Zubay (1962) and charged with ${ }^{3} \mathrm{H}$-methionine (specific activity $3 \mathrm{Ci} / \mathrm{mmole}$, The Radiochemical Center, Amersham, England) by the method of Hoagland et al. (1958) using the rat liver $\mathrm{pH} 5$ enzyme. The specific activity was $1,700 \mathrm{cpm} /$ pmole.

\section{Assay of ribosomal ${ }^{3} \mathrm{H}$-Met-tRNA binding capacity and IF activity}

The incubation mixture for the determination of 
ribosomal capacity to bind ${ }^{3} \mathrm{H}-\mathrm{Met}-\mathrm{tRNA}$ contained $50 \mathrm{mM}$ Tris- $\mathrm{HCl}$ (pH 7.6), $100 \mathrm{mM} \mathrm{NH}_{4} \mathrm{Cl}, 3 \mathrm{mM}$ $\mathrm{MgCl}_{2}, 4 \mathrm{mM}$ mercaptoethanol, $2 \mathrm{mM}$ GTP (Boehringer, Mannheim, Germany), 16 pmoles of ${ }^{3} \mathrm{H}$-MettRNA $(27,200 \mathrm{cpm})$ and $70-90 \mu \mathrm{g}$ of ribosomes (as protein) in a final volume of $0.25 \mathrm{ml}$. Incubations were carried out at $37^{\circ} \mathrm{C}$ for $20 \mathrm{~min}$. After incubation, the reaction mixture was diluted with $3 \mathrm{ml}$ of ice-cold buffer solution containing $50 \mathrm{mM}$ Tris- $\mathrm{HCl}(\mathrm{pH}$ 7.6), $100 \mathrm{mM} \mathrm{NH} \mathrm{NH}_{4} \mathrm{Cl} 7 \mathrm{mM} \mathrm{MgCl}_{2}$ and $4 \mathrm{mM}$ mercaptoethanol and filtered through a Millipore filter (HA $0.45 \mu, 25 \mathrm{~mm}$ ). The filter was washed with $6 \mathrm{ml}$ of the diluting buffer solution and the radioactivity retained on the dried filter was counted in a liquid scintillation spectrometer. Under these incubation conditions, the reaction proceeds with incubation time up to $40 \mathrm{~min}$ but the rate of the reaction showed a tendency of leveling-off after $25 \mathrm{~min}$. The almost linear relationship was observed between the amount of ${ }^{3} \mathrm{H}$-Met-tRNA retained on the filter and the amount of ribosomes added to the incubation mixture up to $400 \mu \mathrm{g}$ (as protein).

The assay of IF activity was carried out by essentially the same method described by Dubnoff and Maitra (1971). The salt-washed ribosomes used in this assay were separated from rat livers and incubated in a complete protein-synthesizing system described by Schreier and Staehelin (1973a) at $35^{\circ} \mathrm{C}$ for $50 \mathrm{~min}$. After the incubation, the mixture was chilled and $4 \mathrm{M} \mathrm{KCl}$ was added to bring the salt concentration to $0.5 \mathrm{M}$. The ribosomes were recovered by centrifugation at $150,000 \times \mathrm{g}$ for $60 \mathrm{~min}$ after stirring the mixture for $60 \mathrm{~min}$ at $0^{\circ} \mathrm{C}$ and then suspended in a medium containing $20 \mathrm{mM}$ Tris- $\mathrm{HCl}$ (pH 7.6), $10 \mathrm{mM}$ $\mathrm{MgCl}_{2}, 30 \mathrm{mM} \mathrm{NH}{ }_{4} \mathrm{Cl}, 10 \mathrm{mM}$ mercaptoethanol and $0.5 \mathrm{mM}$ EDTA. The suspension was passed through a column of Sephadex G-100 $(1 \mathrm{~cm} \times 50 \mathrm{~cm})$ equilibrated with the suspending medium and the ribosomes eluted at the excluded volume were collected. These ribosomes could be stored at $0^{\circ} \mathrm{C}$ for at least 6 weeks without any detectable loss of binding activity. The reaction mixture contained $50 \mathrm{mM}$ Tris- $\mathrm{HCl}(\mathrm{pH}$ 7.8), $100 \mathrm{mM} \mathrm{NH} \mathrm{NH}_{4} \mathrm{Cl} 4 \mathrm{mM} \mathrm{MgCl}_{2}, 4 \mathrm{mM}$ mercaptoethanol, $2 \mathrm{mM} \mathrm{GTP}, \quad 60 \mu \mathrm{g}$ of salt-washed ribosomes (as protein), initiation factor fraction, $6 \mu \mathrm{g}$ of poly AUG (PL Biochemicals Inc., Milwaukee, Wis., U.S.A.) and 8 pmoles of ${ }^{3} \mathrm{H}$-Met-tRNA $(13,600$ $\mathrm{cpm}$ ) in a final volume of $0.3 \mathrm{ml}$. Incubations were carried out at. $37^{\circ} \mathrm{C}$ for $10 \mathrm{~min} .{ }^{3} \mathrm{H}-$ Met-tRNA bound to ribosomes was separated by a Millipore filter as described in the preceding section. One unit of IF was defined tentatively as the amount of IF which provokes binding of 1 pmole of ${ }^{3} \mathrm{H}$-Met-tRNA to salt-washed ribosomes under the incubation conditions described above. Typical reaction curves against increasing amounts of IF are presented in

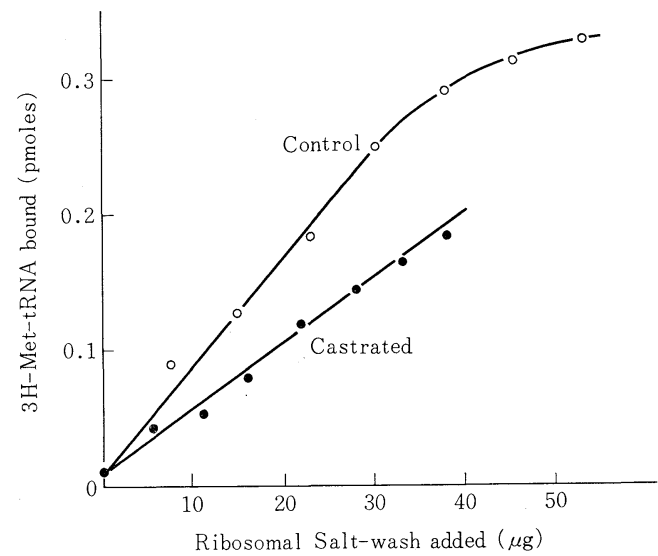

Fig. 1. Effect of various amounts of the ribosomal salt-wash fraction isolated from ribosomes of the ventral prostate of control and castrated rats on the ${ }^{3} \mathrm{H}$-Met-tRNA binding to rat liver saltwashed ribosomes in the presence of poly AUG and GTP.

Fig. 1. The almost linear relationship was obtained between ${ }^{3} \mathrm{H}$-Met-tRNA retained on the filter and the amount of the IF fraction added within a limited range of protein concentrations.

\section{Determination of relative rate of polypeptide elongation}

To assess the relative rate of polypeptide elongation in the ventral prostate from control and castrated rats, the ratio method described by Palmiter (1972) was adopted. $20 \mu \mathrm{Ci}$ of ${ }^{14} \mathrm{C}$-L-Leucine $(300 \mathrm{mCi}$ / mmole, The Radiochemical Centre, Amersham, England) was injected intraperitoneally into one rat and $100 \mu \mathrm{Ci}$ of $4,5-{ }^{3} \mathrm{H}$-L-leucine $(32 \mathrm{Ci} / \mathrm{mmole}$, Daiichi Pure Chemical Co., Tokyo) was injected to another one. Exactly $10 \mathrm{~min}$ later, both animals were sacrificed. The tissues obtained from each animal received ${ }^{3} \mathrm{H}$ - or ${ }^{14} \mathrm{C}$-leucine were combined and the homogenate was prepared as described. The postmitochondrial supernatant prepared after centrifugation at $12,000 \times \mathrm{g}$ for $20 \mathrm{~min}$ was recentrifuged at $105,000 \times \mathrm{g}$ for $60 \mathrm{~min}$ to separate microsomes and cytosol. The microsomal fraction were resuspended in the homogenizing medium and spun down again by centrifugation. Proteins in each fraction was precipitated by adding trichloroacetic acid to a final concentration of $5 \%$. The precipitates were washed twice with ice-cold $5 \%$ trichloroacetic acid and dissolved in $1 \mathrm{~m} l$ of NCS (Amersham/Searle, Arlington Heights, Ill, U.S.A.) for the estimation of radioactivity of ${ }^{3} \mathrm{H}$ and ${ }^{14} \mathrm{C}$ separately. The ratio of ${ }^{3} \mathrm{H}$ to ${ }^{14} \mathrm{C}$ radio- 
activity in the supernatant proteins ( $\mathrm{Sr}$ ) and in the microsomal proteins (Pr) was calculated. The ratio of $\mathrm{Sr} / \mathrm{Pr}$ is an estimate of the difference in the relative rate of elongation in the two tissues.

\section{Other analytical methods}

Protein and RNA were determined by the method of Lowry et al. (1951) and Mejbaum (1939), respectively. The radioactivity of ${ }^{3} \mathrm{H},{ }^{14} \mathrm{C}$ and ${ }^{32} \mathrm{P}$ was counted in a Tri-Carb liquid scintillation spectrometer model $3380.10 \mathrm{ml}$ of toluene containing $0.4 \%$ DPO and $0.01 \%$ POPOP was used for the determination of radioactivity. The radioactivity in the trichloroacetic acid precipitate was determined after dissolving in NCS. An automatic external standardization was applied to quenching correction in each sample.

\section{Results and Discussion}

Poly $A-R N A$ in the nuclear and the cytoplasmic fraction of the ventral prostate from control and castrated rats

It is known that poly $\mathrm{A}$ sequences are a

Table 1. Content of RNAs that contains polyadenylate sequences in fractions of cytoplasm and nuclei of ventral prostate from control and castrated rats.

\begin{tabular}{|c|c|c|}
\hline \multirow{2}{*}{ Tissues from } & \multicolumn{2}{|c|}{$\begin{array}{l}\text { Percent of imput RNA } \\
\text { retained on Poly U filter }\end{array}$} \\
\hline & Nuclear & Cytoplasmic \\
\hline Control & $0.16 \pm 0.02 *$ & $0.19 \pm 0.02^{*}$ \\
\hline Sham-operated (48 hr) & $0.20,0.16$ & $0.21,0.26$ \\
\hline Castrated (48 hr) & $0.14,0.15$ & $0.06,0.04$ \\
\hline
\end{tabular}

* Values expressed as mean \pm standard error of 7 independent experiments. characteristic of all mRNA's in animal cells with the exception of histone mRNA (see a review by Williamson, 1973). Therefore the rate of binding of RNA fractions to immobilized poly $U$ seems to be a feasible method to assess the content of mRNA in tissue extracts. As shown in Table 1, the content of poly A-RNA was markedly reduced in the cytoplasmic fraction from castrated animals, while no significant difference was observed in the poly A-RNA content of nuclear fractions from the tissue of the intact, shamoperated and castrated animals. The incorporation of ${ }^{32} \mathrm{P}$ per gram of wet tissue in cytoplasm of castrated animals was approximately $60 \%$ of that of control animals (Table 2 ), therefore, the concentration of poly ARNA in the castrated cytoplasm was calculated to be approximately $1 / 6$ of that of the control animals. These results may indicate that the processing of transcribed precursor mRNA, such as polyadenylation, cleavage to smaller molecules and transportation from nuclei to cytoplasm (Scherrer, 1963; Nikolaev et al., 1973; Schum and Webb, 1972) seems to be also influenced by castration.

\section{Changes in the ribosomal sedimentation profile after castration and testosterone treatment \\ Castration caused a rapid reduction in poly- ribosomal fraction; the effect was already evident $2 \mathrm{hr}$ after castration and almost back ground level of $260 \mathrm{~nm}$ absorbtion in polyribosomal zone after $24 \mathrm{hr}$ or later (Fig. 2). Injection of testosterone propionate into}

Table 2. Incorporation of ${ }^{32} \mathbf{P}$ into RNA in nuclear and cytoplasmic fractions of rat ventral prostates.

\begin{tabular}{lll}
\hline & \multicolumn{1}{c}{ Nuclear } & \multicolumn{1}{c}{ Cytoplasm } \\
\hline Control & $9.08 \times 10^{6} \mathrm{cpm} / \mathrm{g}$ tissue* & $3.83 \times 10^{6} \mathrm{cpm} / \mathrm{g}$ tissue \\
& $1.83 \times 10^{6} \mathrm{cpm} / \mathrm{mg} \mathrm{RNA}$ & $1.24 \times 10^{6} \mathrm{cpm} / \mathrm{mg} \mathrm{RNA}$ \\
Castrated $(48 \mathrm{hr})$ & $4.69 \times 10^{6} \mathrm{cpm} / \mathrm{g}$ tissue & $2.39 \times 10^{6} \mathrm{cpm} / \mathrm{g} \mathrm{tissue}$ \\
& $1.78 \times 10^{6} \mathrm{cpm} / \mathrm{mg} \mathrm{RNA}$ & $1.41 \times 10^{6} \mathrm{cpm} / \mathrm{mg} \mathrm{RNA}$ \\
\hline
\end{tabular}

* Values are the average of 2 independent experiments.

Each animal received $1.2 \mathrm{mCi}$ of ${ }^{32} \mathrm{P}$-orthophosphate and sacrificed $40 \mathrm{~min}$ later. For other details of the experimental conditions, see the test. 


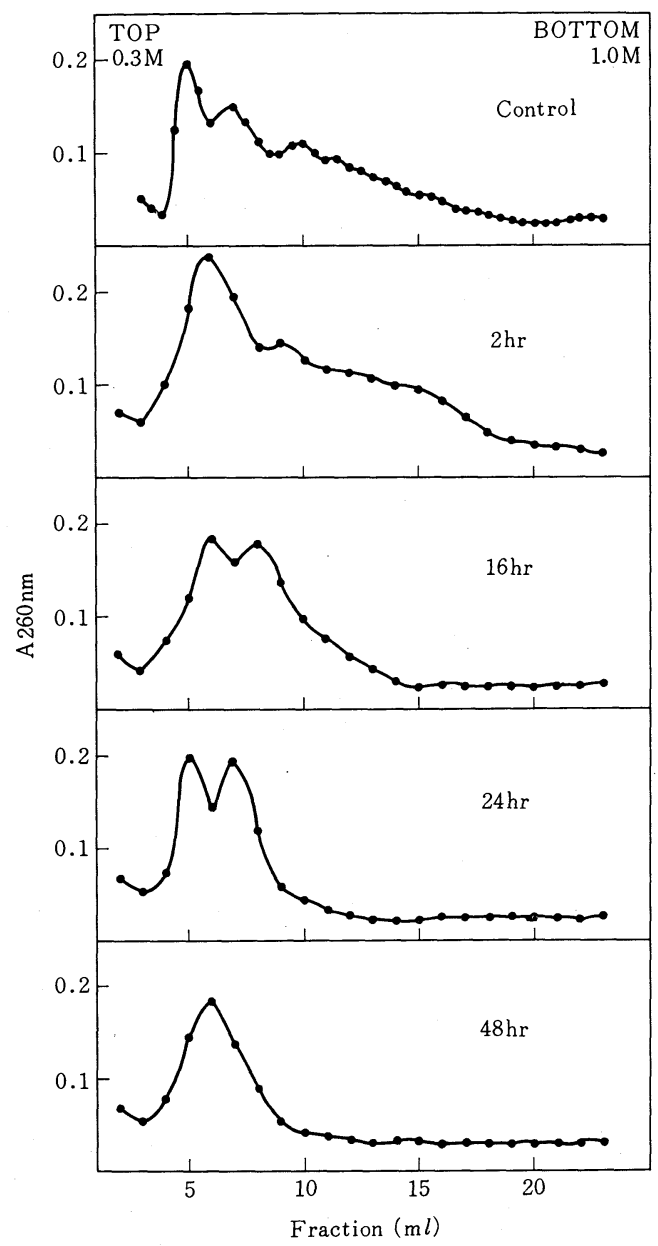

Fig. 2. Changes in the ribosomal sedimentation profile of the rat ventral prostate after castration.

castrated animals ( $24 \mathrm{hr}$ ) induced a relatively rapid reformation of polyribosomes but $48 \mathrm{hr}$ were necessary for the complete restoration of the profile (Fig. 3).

${ }^{3} \mathrm{H}$-Met-tRNA binding to and IF activity in ribosomes from control, castrated and castrated testosterone-treated animals

${ }^{3} \mathrm{H}$-Met-tRNA binding capacity of ribosomes isolates from the ventral prostate of castrated rats ( $48 \mathrm{hr}$ ) was significantly reduced and this was partly restored by supplementing the IF fraction isolated from rat liver (Table

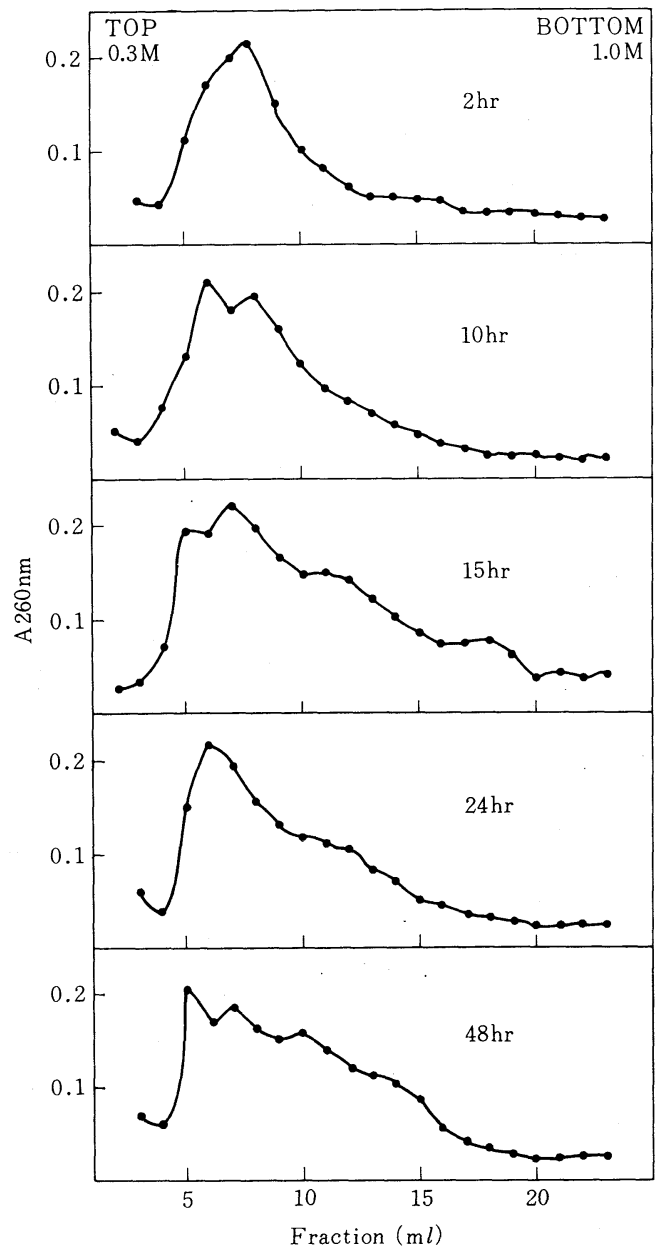

Fig. 3. Changes in the ribosomal sedimentation profile of the ventral prostate from castrated rats after administration of testosterone.

3). Administration of testosterone propionate to castrated animals ( $48 \mathrm{hr}$ ) completely abolished the effect of castration. The ratio of the rate of binding in the presence of IF to that in the absence of IF was significantly higher in castrated ribosomes than in control and this might indicate that the castration caused a decrease in the ribosomal IF content of the tissue. However, in the present experiment, tRNA used for charging with ${ }^{3} \mathrm{H}$-methionine was not fractionated, then the tRNA ${ }_{M}^{\text {met }}$ must also be labelled. Therefore, observed radioactivity retained on the filter would possibly 
Table 3. Effect of castration and testosteronetreatment on the binding activity of ribosomes from rat ventral prostates to ${ }^{3} \mathrm{H}$-Met-tRNA.

\begin{tabular}{|c|c|c|c|}
\hline \multirow{2}{*}{ Animals } & \multicolumn{3}{|c|}{$\begin{array}{l}{ }^{3} \mathrm{H}-\mathrm{Met}-\mathrm{t} \mathrm{RNA} \text { bound (pmoles/ } \\
\text { mg ribosomal protein) }\end{array}$} \\
\hline & $-\mathrm{IF}$ & $+\mathrm{IF}^{*}$ & $+\mathrm{IF} /-\mathrm{IF}$ \\
\hline Intact control & 14.37 & 23.57 & 1.64 \\
\hline$"$ & 16.14 & 23.35 & 1.45 \\
\hline Sham-operated (48 h & r) 14.08 & 21.92 & 1.56 \\
\hline Castrated (48 hr) & 5.89 & 16.73 & 2.81 \\
\hline$"$ & 3.82 & 12.61 & 3.61 \\
\hline Castrated and & 18.06 & 21.07 & 1.17 \\
\hline testosterone-treatec & d 15.58 & 21.84 & 1.40 \\
\hline
\end{tabular}

* $136 \mu \mathrm{g}$ of IF isolated from rat liver ribosomes were added. This amount of IF bound 0.041 pmole of ${ }^{3} \mathrm{H}$-Met-tRNA and this was subtracted from the data of IF-added experiments. For other details of experimental animals and incubation conditions, see the text.

Table 4. IF content in ribosomes of the ventral prostate from intact, castrated and testosteronetreated rats.

\begin{tabular}{lcc}
\hline \multicolumn{1}{c}{ Animals } & $\begin{array}{c}\text { Units/mg } \\
\text { RSW* }\end{array}$ & $\begin{array}{c}\text { Units/mg } \\
\text { Ribosomal } \\
\text { Protein }\end{array}$ \\
\hline Intact Control & 7.97 & 2.11 \\
" & 8.63 & 2.56 \\
Sham-operated (48 hr) & 7.33 & 2.02 \\
Castrated (48 hr) & 5.18 & 1.20 \\
" & 4.55 & 0.93 \\
Castrated and & 8.84 & 2.31 \\
testosterone-treated & 8.26 & 2.19 \\
\hline
\end{tabular}

* Per mg protein in ribosomal salt-wash fraction. For experimental conditions, see the text.

be a sum of the ${ }^{3} \mathrm{H}-$ Met-tRNA in the initiation complex and ${ }^{3} \mathrm{H}$-methionine incorporated into peptide chains. To further clarify the role of the initiation in the hormonal regulation of protein synthesis, IF activity in ribosomes obtained from the ventral prostate of castrated rats was compared with that from control and castrated, testosterone-treated animals. As indicated in Table 4, IF activity in ribosomes from the tissue of castrated animals (48 hr) was significantly lower either on the basis of protein in the ribosomal salt-wash fraction or of protein in ribosomes. Again, the diminished IF activity was commletely restored by the replacement therapy of castrated animals. However, it was noticed in preliminary experiments that the affinity between ribosomes and IF did not seem to be very strong, therefore, a possibility that the decreased ${ }^{3} \mathrm{H}$ Met-tRNA binding capacity and low IF activity observed in ribosomes of castrated rats were caused merely by the decreased affinity of ribosomes with IF which resulted in the liberation of IF during the procedures for preparation of ribosomes, can not be excluded.

From the results obtained, it is suggested that IF is involved in the hormonal regulation of protein synthesis in a male accessary sex organ. A work made by Gambino et al. (1973) also suggests the important role of ribosomal salt-wash fraction in the protein synthesis in which they observed significant differences in acrylamide gel pattern as well as in physiological properties of ribosomal salt-wash fraction between unfertilized and fertilized sea urchin eggs as early as 2 min after fertilization.

In the present study, IF activity only from ribosomes has been examined but it has been reported that proteins required for the initiation of protein synthesis also exist in the cytosol of animal cells in addition to being associated with ribosomes (Fuhr et al., 1969; Sampson and Borghetti, 1972; Schreier and Staehelin, 1973b). The relationships between IF associated with ribosomes and IF associated with cytosol in the regulation of protein synthesis have to be examined.

\section{Effect of castration on the relative rate of polypeptide elongation}

The relative rate of polypeptide chain elongation was examined by the method of Palmiter (1972) in the tissue of control and castrated animals. The method used seems to allow a rough estimation of the difference in the relative rate of elongation between the tissues from two experimental animals. The results obtained 
Table 5. Effect of castration on the relative rate of polypeptide chain elongation in the rat ventral prostate.

\begin{tabular}{|c|c|c|}
\hline \multicolumn{2}{|c|}{ Isotope administered } & \multirow{2}{*}{$\mathrm{Sr} / \mathrm{Pr}$} \\
\hline${ }^{3} \mathrm{H}$-Leucine & ${ }^{14} \mathrm{C}$-Leucine & \\
\hline Control & Control & 1.05 \\
\hline Sham-operated & $"$ & 0.97 \\
\hline Castrated (48 hr) & $"$ & 0.77 \\
\hline " & $"$ & 0.72 \\
\hline$"$ & $"$ & 0.75 \\
\hline
\end{tabular}

* Sr signifies the ratio of ${ }^{3} \mathrm{H} /{ }^{14} \mathrm{C}$ in the cytosol fraction and $\operatorname{Pr}$ signifies the same ratio in the polyribosomal fraction. $\mathrm{Sr} / \mathrm{Pr}$ is an estimate of the difference in the relative rates of elongation in the tissues obtained from two animals.

are summarized in Table 5. The value of 1.05 obtained from two control animals seems to validate the method employed. $23-28 \%$ reduction of the relative elongation was noticed in castrated animals. Sham-operation did not seem to cause any influences.

\section{General Remarks}

In the oviduct of laying hens, the rate of protein synthesis after estrogen stimulation increased 7-fold (Palmiter et al., 1970), while only 2-to 3-fold increase in the translatable mRNA was observed (Palmiter, 1972). From these results, it has been suggested that the 7-fold increase in protein synthesis may stem from an increase in the rate of polypeptide chain initiation, chain elongation or elevated mRNA concentration (Palmiter, 1972). In the present study, it was found that the poly ARNA content in cytoplasm was significantly reduced in castrated animals, while the poly A-RNA content in nuclear fraction was almost similar in two experimental animals. These may indicate that castration influences the transportation of mRNA from nuclei to cytoplasm and also possibly the processing of precursor mRNA in addition to the transcription. Furthermore, the rate of ${ }^{3} \mathrm{H}$-Met-tRNA bind- ing and IF content in the tissue of castrated animals were significantly lower than that of control animals, while the effect of castration on the peptide chain elongation was relatively small. From these observations, it may be safely concluded that in rat ventral prostates, as in oviducts of laying hen, the hormonal regulation of protein synthesis is not restricted at the step of the transcription of translatable mRNA but the site of hormonal regulation is rather widely distributed over several steps of protein biosynthesis. The control mechanisms by hormone in each process of protein biosynthesis still remain to be clarified.

\section{References}

Dubnoff, J. S. and U. Maitra (1971). Methods in Enzymol. ed. by Colwick, S. P. and N. O. Kaplan, Vol $X X$, p. 248, Academic Press., New York, U.S.A.

Fleck, A., J. Shepherd and H. N. Munro (1965). Science 150, 628.

Fuhr, J. E., I. M. London and A. I. Grayzed (1969). Proc. Nat. Acad. Sci., U.S.A. 63, 129.

Gambino, R., S. Metafora, L. Felicetti and J. Raisman (1973). Biochim. Biophys. Acta 312, 377.

Hoagland, M. B., M. L. Stephenson, J. E. Scott, L. H. Hecht and P. C. Zamecknik (1958). J. Biol. Chem. 231, 241.

Lee, S. Y., J. Mendecki and G. Brawerman (1971). Proc. Nat. Acad. Sci., U.S.A. 68, 1331.

Lowry, O. H., N. J. Rosenbrough, A. L. Farr and R. V. Randall (1951). J. Biol. Chem. 193, 265.

Mejbaum, W. (1937). Hoppe-Seyler's Z. Physiol. Chem. 258, 117.

Nikolaeve, N., L. Silengo and D. Schlessinger (1973). J. Biol. Chem. 248, 7963.

Pain, V. M. (1973). FEBS Letters 35, 169.

Palmiter, R. D. (1972). J. Biol. Chem. 247, 6770.

Palmiter, R. D., A. K. Christensen and R. T. Schimke (1970). Ibid. 245, 833. 
Sampson, J. and A. F. Borghetti (1972). Nature New Biol. 233, 200.

Scherrer, K. (1973). Acta Endocr. Supple 180, 95.

Schreier, M. H. and T. Staehelin (1973a). J. Mol. Biol. 73, 329.

Schreier, M. H. and T. Staehelin (1973b). Nature New Biol. 242, 35.

Schum, D. E. and T. E. Webb (1972). Biochem. Biophys. Res. Commun. 48, 1259.

Sheldon, R., C. Jurale and J. Kates (1972). Proc. Nat. Acad. Sci., U.S.A. 69, 417.

Stirewalt, W. S., I. G. Wool and P. Cavicchi (1967). Ibid. 57, 1885.

Thompson, E. B., D. K. Granner and G. M. Tomkins (1970). J. Mol. Biol. 54, 159.

Tomkins, G. M., B. B. Levinson, J. D. Baxter and L. Dethlefsen (1972). Nature New Biol. 239, 9.

Van Venrooje, W. J. W., E. C. Henshow and C. A. Hirsh (1972). Biochim. Blophys. Acta 259, 127.

Vaughan, M. Jr, P. J. Pawlowski and J. Forchhammer (1971). Proc. Nat. Acad. Sci. U.S.A. 68, 2057.

Wettstein, F. O., T. Staehelin and H. Noll (1963). Nature 197, 430.

Williams-Ashman, H. G. and J. Shimazaki (1969). Reproduction and Sexual Behavior, ed. by Diamond M., pp. 241, Indiana Univ. Press, Bloomington, IN., U.S.A.

Williamson, R. (1973). FEBS Letters 37, 1. Zubay, G. (1962). J. Mol. Biol. 4, 347. 